Japanese Research in Business History 2008 | 25

\title{
A Reconsideration of the Corporate Finance of Large Japanese Manufacturing Firms during the Interwar Period
}

\author{
Nao SAITO \\ Waseda University
}

\section{INTRODUCTION}

7 нве овлест of this paper is to reconsider the financing of large Japanese firms in the interwar period, with reference to the 1 characteristics of the Japanese enterprise system at the time.

Decisions concerning the fund-raising are some of the most important corporate decisions to be taken in the management of an enterprise, and a certain amount of research has already been conducted on the fund-raising by Japanese enterprises in the interwar period, predominantly concerning large enterprises, in an attempt to grasp the overall picture. However, this earlier research has generally restricted itself to describing external characteristics, and has not carried out an adequate analysis of the enterprise system, which surely has an intimate relationship to the process of fund-raising. It is necessary to refine our understanding of the procurement of funds in the interwar period, by including an analysis of its relation to the enterprise system.

Scholars of business history are in agreement that one of the characteristics of the interwar enterprise system was the strong authority exercised by shareholders ${ }^{1}$. The background to this strong authority was

1. Typical of the attempts to characterize the interwar enterprise system is the work of 
the structure of corporate finance, based primarily on equity. Previous researches have pointed out this pattern of equity-centered corporate finance, but by undertaking a more detailed discussion of equity-based corporate finance it should be possible to gain a deeper understanding than hitherto of the characteristics of the enterprise system ${ }^{2}$.

In concrete terms, we must consider in detail the trends in fundraising through equities with particular attention to the following factors, which would appear to be closely related to the characteristics of the enterprise system, namely: (1) the significance of the system of paying for stocks by installments ${ }^{3},(2)$ the effects of corporate mergers, and (3) the influence of stock retirement. This paper will therefore attempt an analysis of large-scale mining and manufacturing enterprises $^{4}$ from the above perspective, using aggregate data constructed with firm-year level financial data in the interwar period.

This paper is organized as follows. Section 2, will survey earlier research on the topic, and indicate problematical areas. Section 3 consists of an explanation of the data to be used for analysis. Section 4 is the key section of this paper, and will discuss fund-raising by large Japanese firms in the interwar period, with special attention to its relation to the characteristics of the enterprise system. In order to gain a clearer understanding of the significance of the system of share purchase by installments, Section 4.1 will discuss the differences between the

Tetsuji Okazaki (Okazaki, T., "Kigyō shisutemu [The enterprise system]", Okazaki, T., and Okuno, M., eds., Gendai Nihon keizai shisutemu no genryu [The origins of the contemporary Japanese economic system], Nihon keizai shinbunsha, 1993), and the discussion by Hidemasa Morikawa, which remarked on the development of the managerial enterprise, was also premised on the strength of shareholder authority (Morikawa, H., Nihon keieishi [The history of business in Japan], Nihon keizai shinbunsha, 1981, and Morikawa, H., Toppu manejimento no keieishi [Top management in business history], Yūhikaku, 1996.)

2. This is similar to the way in which, when we consider the issue of the fund-raising by Japanese enterprises in the postwar period, we do so bearing in mind such factors as stable shareholders and the 'main bank' system, that make up the Japanese enterprise system.

3. The system of paying for stocks by installments is a system that shareholders pay for stocks in multiple installments, rather than paying the full face value of a share in one lump.

4. In view of the structure of industry in the interwar period, the analysis of the fundraising by the electric power and railroad industries is as important as that of mining and manufacturing, but the author intends to discuss this in a subsequent paper. 
issue of new shares and subsequent calls on shares ${ }^{5}$. In Section 4.2, in order to understand the increase in corporate scale through mergers, we shall discuss that proportion of the increase in paid-in capital that accompanied mergers. In Section 4.3, while taking it into consideration that the interwar period saw a large number of corporate bankruptcies, we consider just to what extent the capital reductions were carried out. Finally, in Section 5, we summarize the results of our analysis, and consider the significance of these results.

\section{PREVIOUS RESEARCH AND THE ANALYTICAL PERSPECTIVE}

\section{Previous research}

A certain amount of research has already been conducted on corporate finance in the interwar period, predominantly concerning large enterprises, in an attempt to grasp the overall picture.

One of the most important points at issue concerning corporate finance in this period has been the importance of fund-raising through equities, and many researchers have repeatedly confirmed this point ${ }^{6}$. Further, in addition to the importance of equity as a means of raising

5. A subsequent call on shares refers to a demand by an enterprise that shareholders pay in unpaid stock.

6. Ever since the groundbreaking findings by Tachi and Moroi that enterprises in the interwar period had a higher equity capital ratio than in the postwar period (Tachi, R., and Moroi, K., "Senzen sengo no kigyō kin'yū [Prewar and postwar corporate finance]", Tachi, R., and Watanabe, T., eds., Keizai seichō to zaisei kin'y $\bar{u}$ [Economic growth and monetary policy], Iwanami shoten, 1965), there has been a large body of research pointing out this fact. See, for example, Shimura, K., Nihon shihon shijō bunseki [An analysis of the Japanese capital market], Tokyo U.P., 1969; Goldsmith, R. W., The financial development of Japan, 1968-1977, Yale U. P., 1983; Matsumoto, K., Kigyō shūeki to kigyō kin'yū [Corporate profits and corporate finance], Nihon keizai shinbunsha, 1986; Asajima, S., "Daikigyō no shikin chōtatsu [Fund procurement by large enterprises]”, Yui, T., and Daitō, E., eds., Nihon keieishi 3: daikigyō jidai no tōrai [The history of Japanese management 3: the advent of the age of the large firm], Iwanami shoten, 1995; and Fujino, S., and Teranishi, J., Nihon kin'yū no sūryō bunseki [Quantitative analysis of Japanese finance], Tōyō keizai shinpōsha, 2000. Further, in Hoshi, T. and Kashyap, A., Corporate Financing and Governance in Japan: The Road to the Future, MIT Press, 2001, which gave an overview of the history of finance in Japan, this point is considered as a 'stylized fact'. 
funds, research hitherto seems to agree on two other points: (1) the fact that, particularly in the $1920 \mathrm{~s}$, corporate bonds became an important means of raising funds, and (2) that, throughout the period, borrowing from banks did not play a significant role.

Moreover, particularly in recent years, there have been efforts, as yet limited in scope, to obtain a full understanding of fund-raising by large enterprises in the interwar period, making use of firm-level financial data. Kaichi Shimura's research has produced pioneering results in this field ${ }^{7}$. For the second half of each of the years 1914, 1919, 1931 and 1936 he carried out analysis of long term funding, using aggregated data, for industrial enterprises (excluding financial and commercial enterprises) that had remained in existence throughout this period. Shōichi Asajima ${ }^{8}$ calculated aggregate figures for large enterprises for each of 5 points in time (the first half of each of the years 1911, 1919, 1926, 1931 and 1936), in respect of (1) working capital, (2) fixed and liquid assets, (3) external finance (bills payable, borrowings, corporate bonds), and (4) internal finance (paid-in capital, reserves, profits). By comparing these for the above 5 points in time, he attempted to identify the characteristics of corporate finance in the interwar period. The analysis in this research was comprehensive in scope, trying, for example, to distinguish between industrial sectors, and between zaibatsu and non-zaibatsu firms, and resulted in a wealth of new findings.

The research of Shōzaburō Fujino and Jūrō Teranishi ${ }^{9}$ analyzed the financial structure mainly of six industries: mining, manufacturing, electricity, gas, railroads and shipping for three periods: 1902 to 1915, 1914 to 1930 , and 1928 to 1940 (with some overlap). They also presented some interesting points, making comparisons with small-scale enterprises, for example, and discussing the reasons for intra-industry differences in fund-raising behavior. Further, by analyzing the data for each year, it was possible for them to discover time-series trends in fund-raising behavior. In this sense their work can be regarded as an extension of the research of Shimura and Asajima.

Nevertheless, all the above research treats increases in capital as simply differences in the volume of paid-in capital, and does not make it

7. Shimura, op. cit.

8. Asajima, op. cit.

9. Fujino and Teranishi, op. cit. 
clear whether this was a result of new share issues, of subsequent payments of partly-paid stock, or a result of corporate mergers. A further problem is that they do not consider the effects of capital reduction, which was very common during the interwar period. To elucidate these points it is insufficient simply to aggregate the differences in paid-in capital; data must be constructed in a way that separates out the changes in paid-in capital into the above-mentioned elements.

\section{Analytical perspective}

Bearing in mind the above survey, it is appropriate to make clear our analytical standpoint. In analyzing the corporate finance in the interwar period from our standpoint, the following points are important.

First, although it has already been seen that earlier research has pointed to the importance of equity in corporate finance in the interwar period, we need to emphasize a strong possibility that, there was a difference in the significance between increases in capital through the issue of new shares, and increases resulting from subsequent payment for partly-paid stocks. It is well known that one of the characteristics of corporate finance in the interwar period was the system of paying for stocks in multiple installments ${ }^{10}$, and compared with the issue of new shares, calls on the shareholders for unpaid stocks were considered as a means of fund-raising allowing wider managerial discretion in the use of the funds. We surely need to clarify the role of a means of fund-raising which has those characteristics. By investigating whether it was in times when the management environment was favorable or unfavorable that this means of fund-raising was mainly used, we will be able to ascertain the economic significance of the system of payment for stocks by installments.

Secondly, increases in paid-in capital were achieved not only through this type of internal growth, but also through mergers with other firms. The progress of research in recent years has shown that there was a

10. See, for example, Shimura, op. cit.. This fact is also pointed out in, for example, Imuta, Y., Meiji-ki kabushiki kaisha bunseki josetsu [Introduction to the analysis of the joint-stock company in the Meiji period], Hosei University Press, 1976, and Noda, M., Nihon shōken shijo seiritsushi [History of the establishment of the Japanese securities market], Yūhikaku, 1980. 
large number of mergers and acquisitions between firms in the interwar years ${ }^{11}$. Mergers bring the possibility of changes in capital, and if a merger takes place through the exchange of shares, it implies an increase in the paid-in capital of the merged firm. This type of increase in capital through merger is not accompanied by any increased investment on the part of the shareholders of the merged firm, and should be distinguished from normal internal growth due to increased capitalization.

Thirdly, it is well known that the Japanese economy in the interwar period saw numerous failures of large companies ${ }^{12}$. This being the case, in order to discuss the changes in amounts of paid-in capital over time, it is necessary to eliminate the effect of the retirement of shares. If, for example, at a time when paid-in capital was increasing, there was also a large scale retirement of shares, the actual amount of newly-raised capital will have been larger than the apparent amount. We have to take all the above points into account when considering corporate finance in the interwar period.

III DATA USED AND THE SCOPE OF ANALYSIS

\section{Data}

The data to be used for analysis in the Section is as follows. First, we selected as sample firms the top 100 corporations in the list of large mining and manufacturing enterprises compiled by Mark Fruin ${ }^{13}$. For large companies it is not unusual for a complete series of company

11. For the large number of corporate mergers in the interwar years, see Miyajima, H., "Kyūzō-suru M\&A wo ika ni rikai-suru ka [How should we interpret the increase in M\&A?]", RIETI Discussion Paper Series, 06-J-044, 2006.

12. An example of research referring to the frequency of entry and exit by firms in the Japanese economy in the interwar years is Teranishi, J., Nihon no keizai shisutemu [The Japanese economic system], Iwanami Shoten, 2003. For a contemporary view of corporate failure in the interwar years, see Takahashi, K., Kabushiki kaisha bōkokuron [The joint-stock company - the ruination of the nation], Banrikaku shobō, 1930.

13. Fruin, M., The Japanese Enterprise System: Competitive Strategies and Cooperative Structures, Clarendon Press, 1992, Appendix A-1. 
reports for each accounting period to remain in existence to the present day, but there is a tendency for the smaller the scale of company is, the more difficult it is to obtain data covering the entire period. Consequently we had no alternative to limit the number of sample firms in the analysis to this number. While on one hand the analysis in this paper is excellent in that it use detailed time-series data, on the other hand, it must be admitted that it suffers from limitations in the breadth of the firms used in the analysis. For reference, looking at the weight of these companies in the total of Japanese joint-stock companies, the total paid-in capital of these 100 firms was $¥ 832.45$ million, amounting to $20.1 \%$ of the $¥ 4,143.13$ million total capital of all joint-stock companies at the time ${ }^{14}$.

For these top 100 mining and manufacturing companies as of 1918 , we traced later changes in paid-in capital. The data sources were Toyō keizai shinpōsha Kabushiki kaisha nenkan [Joint stock company yearbook], Ōsakaya shōken [Ōsakaya Securities], Kabushiki nenkan [Shares yearbook], and Yamaichi shōken [Yamaichi Securities], Kabushiki shasai nenkan [Stock and corporate bond yearbook] for successive years, and the financial reports of each company. More precisely, we examined the figures for capital and unpaid capital using the numerical information obtained from the balance sheets in these various data sources, and created data series for paid-in capital from the difference between those two items.

As factors bringing about increases in paid-in capital the following three are should be considered: (1) an increase due to a new share issue (capital increase); (2) demands for the payment for unpaid capital (decrease in unpaid capital) ; and (3) an increase in capital due to a merger with another company. Further, corporate failures were common in the interwar period, and as a result there were frequent cases of capital decrease (retirement of shares), so in order to analyze fundraising behavior from the changes in the figures in the balance sheets, we should be aware of the necessity to include (4) exclusion of the effect of capital reduction. The sum of these four factors result in the increase or decrease in paid-in capital in each period. From the

14. The top 200 companies account for $¥ 1011$ million, $24.4 \%$ of the total. The total amounts are from Naikaku tōkeikyoku [Cabinet Statistics Bureau], Kigyō no hatten to shihon no shūseki [Corporate development and capital accumulation], 1929. 
information concerning new share issues, calls for payment of unpaid capital, corporate mergers and capital reduction, we can construct data series for each of the above four factors influencing changes in the amount of paid-in capital ${ }^{15}$.

\section{An overview of corporate finance}

As we have confirmed in the previous section, previous researches on fund raising by Japanese enterprises in the interwar period has asserted the importance of equity in the sources of funding for large enterprises. Before embarking on our analysis, we would like to confirm that the above assertion is supported by the data used in this paper.

Aggregated values for the increases and decreases in the value of corporate bonds and borrowings; and for increases in paid-in capital are shown in Table 1. Increases in paid-in capital in this table are values with the influence of capital reduction excluded. However, for corporate bonds and borrowings, changes in the outstanding balance are determined by decreases due to repayments, and by increases due to new fund-raising. It is not possible to differentiate between amounts of repayment and of new fund-raising for each individual enterprise. However, when aggregating the figures for each period, by aggregating separately the figures for enterprises where the outstanding balance has increased, and those where it has decreased, it is possible to arrive at an approximation - albeit with a certain amount of errors - for the total amounts of repayment and of newly raised funds. These figures were obtained for each accounting period, and the figures for the first and second periods added together to give annual data.

In terms of newly raised funds, we see from this table that in the latter half of the 1920s fund raising through corporate bonds was on a

15. There are some very short periods for which financial data are unavailable, since the records no longer exist. In these cases, for the numerical series for the amount of capital, the figures have been estimated using historical data published later in Tōyō keizai shinpōsha Kabushiki kaisha nenkan [Joint stock company yearbook], or capital movement tables in Yamaichi shōken [Yamaichi Securities], Kabushiki shasai nenkan [Stock and corporate bond yearbook] and similar sources. For company bonds and borrowings, referred to later, linear interpolation was used. The number of firms for which this method was necessary was small, Fujita Mining, Noda Soy Sauce, Asano Shipyards and a very few others, and for extremely short periods. 
Table 1 Breakdown of Fund-Raising (Corporate Bonds, Borrowings, Paid-in Capital)

(Unit: $¥ 1,000$ )

\begin{tabular}{|c|c|c|c|c|c|c|c|}
\hline \multirow{2}{*}{$\begin{array}{l}\text { Accounting } \\
\text { period }\end{array}$} & \multirow{2}{*}{$\begin{array}{l}\text { Number } \\
\text { of firms }\end{array}$} & \multicolumn{2}{|c|}{ Corporate bonds } & \multicolumn{2}{|c|}{ Borrowings } & \multirow{2}{*}{$\begin{array}{c}\text { Increase } \\
\text { in paid-in } \\
\text { capital }\end{array}$} & \multirow{2}{*}{$\begin{array}{c}\text { Total } \\
\text { value of } \\
\text { increase }\end{array}$} \\
\hline & & Increase & Decrease & Increase & Decrease & & \\
\hline 1918 & 98 & 25,708 & $\Delta 4,796$ & 32,721 & A 5,495 & 133,172 & 191,601 \\
\hline 1919 & 98 & 31,508 & $\Delta 5,017$ & 28,588 & $\Delta 19,315$ & 118,423 & 178,519 \\
\hline 1920 & 96 & 15,269 & $\Delta 16,445$ & 66,888 & $\Delta \mathbf{1 0 , 2 5 9}$ & 288,735 & 370,892 \\
\hline 1921 & 94 & 36,826 & $\Delta 16,854$ & 68,213 & $\Delta 30,258$ & 121,344 & 226,383 \\
\hline 1922 & 92 & 21,770 & - 16,480 & 29,628 & $\Delta 35,905$ & 50,772 & 102,170 \\
\hline 1923 & 89 & 45,520 & $\Delta 36,487$ & 39,660 & $\boldsymbol{\Delta} 9,614$ & 68,784 & 153,964 \\
\hline 1924 & 89 & 64,094 & $\Delta{ }_{13,853}$ & 43,777 & $\Delta 29,190$ & 89,685 & 197,556 \\
\hline 1925 & 89 & 126,645 & $\boldsymbol{\Delta} 11,253$ & 34,012 & A 37,759 & 68,316 & 228,973 \\
\hline 1926 & 87 & 92,993 & $\Delta$ 23,209 & 43,465 & $\Delta \mathbf{1 8 , 5 9 5}$ & 71,844 & 208,302 \\
\hline 1927 & 83 & 86,303 & $\Delta$ 23,996 & 63,539 & A 33,634 & 109,295 & 259,137 \\
\hline 1928 & 82 & 109,255 & $\Delta 36,934$ & 71,973 & $\Delta 62,112$ & 68,688 & 249,916 \\
\hline 1929 & 81 & 60,536 & $\Delta 43,374$ & 57,322 & A 26,187 & 26,907 & 144,765 \\
\hline 1930 & 81 & 28,750 & $\Delta{ }_{10,568}$ & 25,234 & A 18,358 & 24,438 & 78,422 \\
\hline 1931 & 79 & 27,009 & $\Delta 21,737$ & 34,870 & A 43,059 & 54,520 & 116,399 \\
\hline 1932 & 79 & 16,263 & $\Delta 70,900$ & 18,663 & $\Delta 49,854$ & 40,959 & 75,885 \\
\hline 1933 & 77 & 96,903 & $\Delta 76,384$ & 57,760 & $\Delta 61,224$ & 190,242 & 344,905 \\
\hline 1934 & 73 & 27,122 & $\Delta 57,836$ & 9,475 & $\Delta 57,932$ & 111,045 & 147,642 \\
\hline 1935 & 70 & 26,860 & $\Delta 47,811$ & 22,852 & A 29,157 & 57,896 & 107,608 \\
\hline 1936 & 70 & 14,933 & $\Delta 67,086$ & 72,985 & $\Delta 44,450$ & 119,100 & 207,018 \\
\hline 1937 & 67 & 26,550 & $\Delta 32,586$ & 70,217 & $\Delta 40,241$ & 298,834 & 395,601 \\
\hline 1938 & 67 & 138,904 & $\Delta 16,658$ & 113,940 & A 100,969 & 235,121 & 487,965 \\
\hline 1939 & 65 & 157,864 & $\Delta 19,778$ & 156,843 & $\Delta 29,028$ & 232,163 & 546,870 \\
\hline 1940 & 63 & 89,944 & $\boldsymbol{\Delta} 15,494$ & 198,178 & A 29,887 & 485,845 & 773,967 \\
\hline 1941 & 58 & 240,235 & $\Delta 11,620$ & 248,857 & $\Delta 19,049$ & 409,380 & 898,472 \\
\hline 1942 & 56 & 182,945 & $\boldsymbol{\Delta} 22,069$ & 154,413 & A 103,803 & 421,889 & 759,247 \\
\hline
\end{tabular}

Notes: (1) Following Mitsubishi keizai kenkyūsho, Honpō jigyō seiseki bunseki, February has been taken as the end of the financial year.

(2) 'Increase in paid-in capital' shows newly-raised funds, excluding the effect of capital reductions.

Source: Prepared from company reports and finanancial statements in Tōyō keizai shinpōsha, Kabushiki kaisha nenkan [Joint-stock company yearbook].

massive scale, and between 1925 and 1930 exceeded the sum raised through equity in nearly every year. As has been pointed out in previous researches ${ }^{16}$, corporate bonds were outstandingly important during the

16. For example, Tables $2-12$ in Matsumoto, op. cit., while they paint only a rough picture, at intervals of 5 years, show, if we consider flow data, that in the fund acquisition of large enterprises corporate bonds accounted for over $40 \%$ of the total of shares, corporate bonds, and loans. 
1920s. If we calculate the proportion accounted for by corporate bonds in total corporate finance for the period referred to above $(1925-1930)$, we find that the figure is as high as $43.1 \%$. We therefore agree with the accepted view that in fund raising by large enterprises in the latter half of the 1920s, corporate bonds played a major role.

However, if we estimate the volume of newly-raised funds, taking into account repayments as mentioned above, we find that apart from the second half of the $1920 \mathrm{~s}$, the figures for corporate bonds and borrowings do not nearly approach those for the increase in paid-in equity capital. As Table 1 shows, even if we take newly raised funds as our standard, the proportion of funds raised through equity is the highest in virtually every period, a tendency which holds true even for the wartime period, in which it is generally considered that the importance of bank loans increased. Below, therefore, the analysis will concentrate on the raise of funds through equity, with, in addition, a discussion of the three points that require consideration when we take the characteristics of the enterprise system into consideration: (1) the significance of the system of payment of stocks by installments, (2) the effects of corporate mergers, and (3) the effects of capital reduction.

\section{DISAGGREGATION OF THE FACTORS BEHIND THE INCREASE IN PAID-IN CAPITAL}

In this section we shall discuss the raise of funds through equity in the interwar period, and as mentioned above, this will be done from the perspective of its relationship with the enterprise system of the time. The discussion will be carried out in the following order: (1) the significance of the system of paying for stocks by installments, (2) the effects of corporate mergers, and (3) the effects of capital reduction. Table 2 shows the increase in paid-in capital, separated into four categories: new share issues; calls for the paying in unpaid capital; mergers; and capital reduction. The left-hand side (a) of this table shows aggregated data for all the sample firms, and the right-hand side (b) data for the 70 companies that continued in operation through to 1936. Whereas the former attempts to paint a picture of the overall situation, by using as much data as possible, the latter presents a data series appropriate for comparisons between differing points in time, by 


\begin{tabular}{|c|c|c|c|}
\hline & \multicolumn{2}{|c|}{ 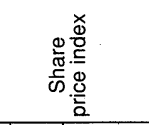 } & 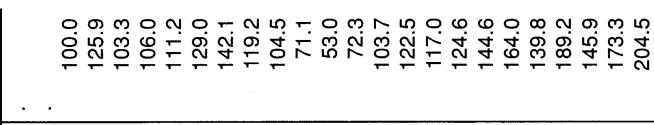 \\
\hline & \multirow{2}{*}{ 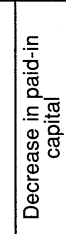 } & 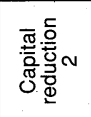 & 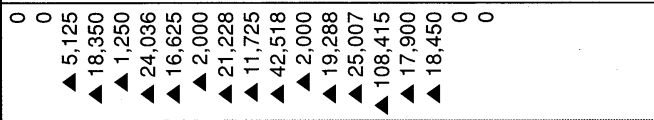 \\
\hline & & 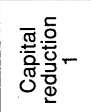 & 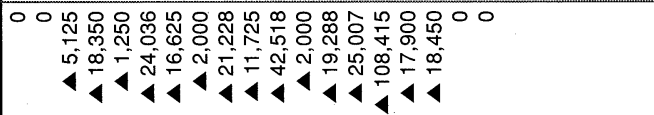 \\
\hline \multirow{5}{*}{ 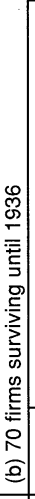 } & \multirow{4}{*}{ 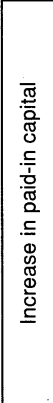 } & 吾 & 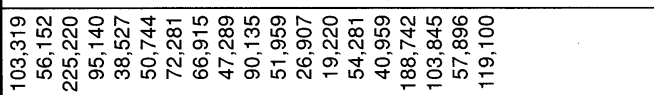 \\
\hline & & $\frac{\omega}{\bar{\omega}}$ & 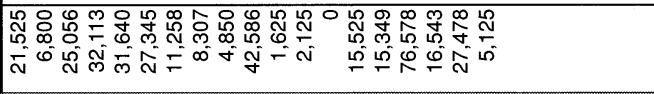 \\
\hline & & 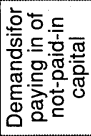 & 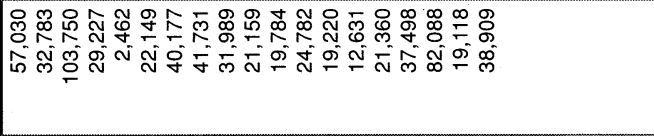 \\
\hline & & 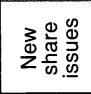 & 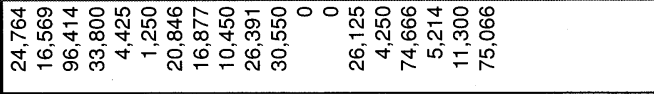 \\
\hline & \multicolumn{2}{|c|}{ 离 } & 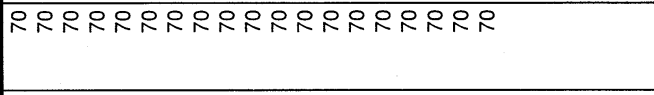 \\
\hline & \multirow{2}{*}{ 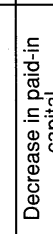 } & 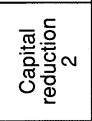 & 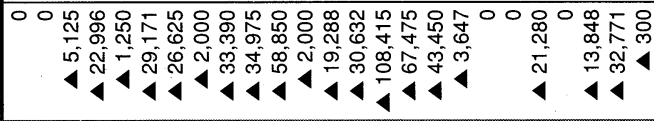 \\
\hline & & 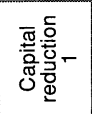 & 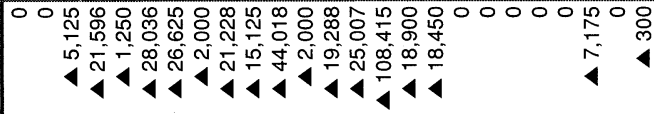 \\
\hline & \multirow{4}{*}{ 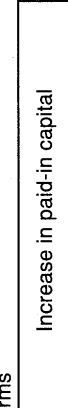 } & 䙲 & 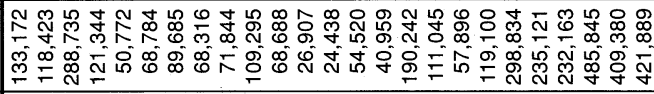 \\
\hline & & $\frac{2}{\frac{2}{0}}$ & 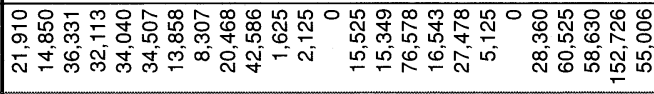 \\
\hline & & 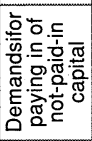 & 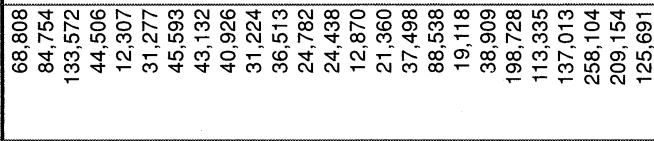 \\
\hline है & & 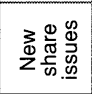 & 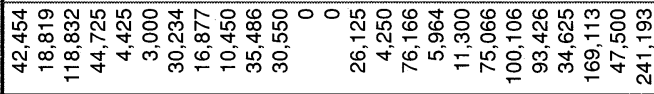 \\
\hline \multirow[t]{2}{*}{$\begin{array}{l}\overline{\mathbb{\Xi}} \\
\mathbb{\Xi}\end{array}$} & & है & 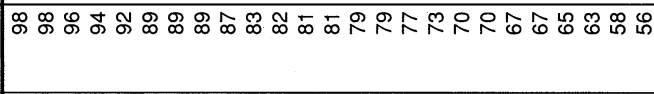 \\
\hline & & & ద్ \\
\hline
\end{tabular}


considering the same companies over time. The trends that can be perceived in the two data sets are roughly the same. We shall pursue our discussion below, using this table.

\section{New share issues and the paying-in of unpaid capital}

In a consideration of the raise of funds through equity, the system of payment for stocks by installments is an important issue. The generally accepted view among researchers of financial history is that, together with stock-collateralized financing ${ }^{17}$, the system of payment for stocks by installments made it possible for enterprises to start smoothly on the road to growth, even in the early stages of economic development, when there was a low level of capital accumulation. However, when this system is considered from the point of view of the enterprise, a call for the paying-in of unpaid capital is a method of fund-raising where it is easy for the management side to ensure the managerial discretion ${ }^{18}$. It is likely, in other words, that it is a method by which an enterprise can raise funds relatively easily, even in conditions where the capital market is tight. The existence of such a discretionary fund-raising method has the effect of making two things possible: it can provide support for fund-raising for a growing company to seize a business opportunity, and enable the postponement of necessary corporate restructuring in a mature enterprise with few prospects for growth ${ }^{19}$. It is surely necessary to consider the economic significance of the system of share payment by installments, by separating increases in paid-in capital into the two components of new share issues, and subsequent calls for paying-in of unpaid capital, and, in particular considering the significance of the

17. Stock-collateralized financing is a method of financing in which a bank lends funds with already-purchased shares as collateral. This makes it easier for shareholders to subscribe newly issued stocks or respond to demands for the paying-in of unpaid capital.

18. See, for example, Noda, op. cit.

19. This argument corresponds to the facts pointed out by researchers in the field of finance, that the possession of access to sources of low-cost funds can on the one hand alleviate the problems of under-investment by growth enterprises, and on the other invite over-investment by mature enterprises. For the former point, see Fazzari, S. M., R. G. Hubbard and B. C. Petersen, "Financing Constraints and Corporate Investment," Brookings Papers on Economic Activity, 1, pp.141-195, 1988, and for the latter, Hadlock, C. J., "Ownership, Liquidity, and Investment," RAND Journal of Economics, 29-3, pp.487-508, 1998. 
latter.

From Table 2 we can draw the following conclusions concerning the trends in the amount of funds raised respectively by new share issues, and the subsequent payment for unpaid stocks. First, we can say that the trend in new share issues is generally linked to changes in business conditions. The right-hand side of Table 2 shows movements in the stock price index, from which we can see that there is a tendency for new share issues to take place when stock prices are high. Since the issue of new stock required the consent of shareholders ${ }^{20}$, and at this time share issues were typically carried out by the allotment to shareholders ${ }^{21}$, this consent could probably only be obtained when share prices were high. This argument is supported by the fact that almost no new share issues were executed when economic conditions were deteriorating. During 1929 and 1930, when share prices were falling continuously, there was not a single new share issue, even though there were 81 of our surveyed companies in existence. It seems that new share issues were difficult when stock prices were stagnating.

Nevertheless, since in the interwar period the issue of new shares was not permitted unless the paying-in of unpaid capital had been completed $^{22}$, the possibility cannot be neglected that the reason for the absence of new share issues was that it was impossible for the great majority of enterprises to issue new shares. Let us consider, therefore, how many enterprises able to issue new shares there were in the period immediately preceding 1929-1930. Since in the second period of 1928 , according to their financial statements, there were 18 out of 81 companies $^{23}$ that had no outstanding unpaid capital, it is not the case that it was impossible for any of these companies to issue new shares. It therefore seem unnecessary to amend our conclusion that the issue of new shares was linked to share price levels.

20. Changes in the amount of authorized capital required a resolution at the general meeting of shareholders.

21. Shimura, op. cit., pp.221-222 and Table 4-11.

22. Under Article 210 of the Commercial Code.

23. The 18 companies were: Dai-Nihon Spinning, Mitsubishi Steel, Furukawa Mining, Japan Steel Works, Kamaishi Mining, Kobe Steel Works, Osaka Gōdō Spinning, Shibaura Electric, Ishikawajima Shipyards, Yokohama Dock, Osaka Ceramics, Japan Flour Mills, Japan Printed Cotton, Wakayama Spinning, Tokyo Steel Products, Japan Pigment Manufacturing, and Japan Leather. 
Secondly, as far as demands for paying-in of unpaid capital is concerned, in contrast to new share issues, which were correlated with the share price, it is important to note that they remained steady even during periods of low share price levels. Even in the 1920s, when the Japanese economy was suffering from prolonged stagnation, the total of these payments of unpaid capital remained stable. Further, even around 1930 , when share prices plummeted, and there were no new share issues whatsoever, if continued at the $¥ 24$ million to $¥ 25$ million level, except for 1931 , when it fell to something over $¥ 12$ million. This suggests that calling for the paying-in of unpaid capital was not necessarily a method of fund-raising that reflected the interests of shareholders ${ }^{24}$.

It is of course possible that the only a small number of good-standing companies utilized calls for payments of unpaid stocks at periods when the economy was languishing. And if we look at the fundraising activities of the firms that disappeared in the period up to 1936, from the difference between the values for (a) and (b), it is found that even firms that ceased operations during the interwar period were demanding the paying-in of unpaid capital. It is likely that nearly all of these firms were facing some sort of management problems ${ }^{25}$, but the existence of this discretionary method of fund-raising may possibly have enabled these firms to survive despite the operational problems they were facing.

\section{Internally-financed growth and mergers}

An increase in paid-in capital can result from a merger with another firm. Several researches in recent years have shown that there were a large number of mergers and acquisitions in the interwar period. Consequently, if we are to consider corporate finance in the interwar period, we must clarify to what extent paid-in capital increased as a result of mergers.

Hideaki Miyajima has already attempted a quantitative assessment of

24. There remains the problem of reconciling this point with the strong shareholder power characteristic of Japanese business in the interwar period, but the author will leave this issue for investigation at a later date.

25 . Virtually all the firms that ceased operations were taken over by other firms, and from the high level of discount on their shares, exchanged at the time of these mergers, we can assume that they were facing management problems of some sort. 
corporate mergers in the interwar period ${ }^{26}$. In this research, the method Miyajima adopted was to investigate the number of mergers, using the lineage trees of each enterprise ${ }^{27}$, aggregate them, and obtain an overall picture over time of the trends in the number of mergers in the Japanese economy as a whole. The methodology has a purpose to grasp the number of mergers as far as possible. The above-mentioned materials took as the sample the corporations that had survived at the time the lineage trees were constructed, and, therefore, there is a problem about the sample selection, as well as the problem arising from the fact that dealing with corporate mergers in terms of the number of cases ignores the question of the scale of the corporations involved - with each individual case being treated equally. Nevertheless, if we take it into consideration that the analysis dealing with a period when no statistical materials concerning mergers were compiled, this method can be regarded as having a certain degree of validity. In this paper, however, we attempt to grasp the quantitative scale of corporate mergers using a different methodology.

Table 2 above shows the trends in the part of the increase in paid-in capital of large companies accounted for by the mergers of other companies. The fact that large-scale mergers - such as those of Nihon Steel, Oji Paper, Dai Nihon Beer and Toyo Spinning - took place in the first half of the 1930s is well-known, and Miyajima, op. cit., regards the 1930 s as the prewar peak for corporate mergers. However, Table 2 suggests that corporate mergers in the 1920 s had reached a level that should not be ignored ${ }^{28}$. Judged in terms of their contribution to the increase in paid-in capital, the importance of corporate mergers in the

26. Miyajima, op. cit.

27. Hideaki Miyajima's research make use of Yagura, S. and Ikushima, Y., Shuyō kigyō no keifuzu [Lineage trees of major corporations], Yūshōdō shuppan, 1983. This work organized the lineages of large Japanese corporations surveyed by the Center for Documentary Analysis of Management, Kobe University Research Institute for Economics and Business Administration.

28. Since Nihon Steel is not included in the sample firms of this paper, the scale of mergers in the $1930 \mathrm{~s}$ is understated, but since other large-scale mergers - Toyo Spinning, Dai Nihon Beer, and Oji Paper, for example - are included, the problem caused by this omission is a limited one. Moreover, the case of Nippon Steel can be regarded as a special case, of a corporate merger centering on Yahata Steel Works, a state-owned enterprise, so that the sample selection for the analysis in this paper can be regarded as acceptable, and as not causing a major problem. 
1920s can be said to be higher than in the 1930s. A detailed consideration of the background of individual mergers in this period is outside the scope of this paper. Nevertheless, as will become clear in the following section, in the period from the 1920 s through to the early 1930s, there was an extremely large number of cases of capital reduction by large firms. This capital reduction, moreover, included huge sums accounted for by discounted shares exchanged on the occasion of corporate mergers. From this it is possible to deduce that there was a considerable number of cases where firms in operating difficulties were merged ${ }^{29}$.

Mergers have a variety of implications for corporate management. For the firm trying to merge other firms, it can be seen as part of its growth strategy. The rationalization of the management of the predecessor company after the merger can also be considered as contributing to an improvement in the efficiency of the economy as a whole. Further, it $\mathrm{s}$ well known that in American-style corporate governance terms, M\&A plays an important role in enforcing management discipline. However, the fact that there were a large number of mergers in the 1920s, a period of chronic recession, surely suggests that there were many firms rescued from collapse by being merged by other firms. This will become even clearer below, where we consider the issue of capital reduction.

\section{The scale of capital reduction}

In the Japanese economy in the interwar period there were frequent corporate failures. Since we can assume that many failed companies were absorbed by other firms, it is likely that the many corporate mergers we identified in the previous section reflect the frequency of corporate failures. It is also probable that we can see the fact that capital reduction were also frequent in the interwar period as a result of these frequently-occurring corporate failures.

Table 2 shows aggregated figures for decreases in the total of paid-in

29. It has been pointed out, for example, that in the cotton-spinning industry in the 1920 s there were many instances of small and medium spinning companies in difficulties being rescued by being taken over by large firms (Iijima, M., Nihon bōsekishi [A history of spinning in Japan], Sōgensha, 1949). 
capital resulting from capital reductions. The column 'Capital reduction 1 ' in this table shows aggregated values for 'normal' capital reductions, while the column 'Capital reduction 2' shows total values including discounted shares exchanged when a firm was subject to takeover ${ }^{30}$. Table 3 additionally shows cases of capital reduction in the interwar period where the scale of capital reduction was particularly large.

It should be noted that, as Table 2 indicates, the decrease in paid-in capital in the interwar period due to capital reductions was extremely large. The total of 'normal' capital reduction in the interwar period, shown in 'Capital reduction 1', amounted to $¥ 360$ million, and if we add in the figure for capital reduction due to shares discounted when a company was taken over ('Capital reduction 2'), the figure amounts to $¥ 490$ million. Since the total of paid-in capital for these 100 firms in 1919 was approximately $¥ 900$ million, and the total value of capital raised through equity between 1920 and 1932 was around $¥ 1,500$ million, we can see how large the figures show in Table 2 for capital reduction were. In 1932, for example, the figure exceeded $¥ 100$ million $^{31}$. Further, as Table 3 shows, individual cases where the level of capital reduction amounted to over half of the total of paid-in capital were by no means unusual. We can see, therefore, that in the interwar period there were frequent instances of large-scale capital reduction.

As already mentioned, in the enterprise system of the interwar period, shareholder carried a lot of weight. At the same time, however, there were many cases where firms' financial stability was lost due to an over-emphasis on the distribution of profits to shareholders. It is possible, consequently, to regard the frequent occurrence of large-scale capital reductions as the unavoidable cost entailed by a shareholderdominated enterprise system. According to economic theory, it is assumed that monitoring by shareholders can enforce discipline on corporate management ${ }^{32}$, but we should not ignore the fact that a

30. This is because, when shares are discounted at the time of an exchange of shares, as far as the shareholders of the company taken over are concerned, this effectively means a reduction of capital.

31. These figures refer only to mining and manufacturing. If the electric power and railroad industries were included, they would obviously be considerably higher.

32. Shleifer, A. and Vishny, R., "Large Shareholders and Corporate Control," Journal of Political Economy, 94-3, pp.461-488, 1986 assert the effectiveness of monitoring by large shareholders. 
Table 3 Large-Scale Capital Reductions in Mining and Manufacturing Firms in the Interwar Period

(unit: $¥ 1,000$ )

\begin{tabular}{|c|c|c|c|c|}
\hline & Company & $\begin{array}{l}\text { Accounting } \\
\text { period }\end{array}$ & $\begin{array}{l}\text { Amount } \\
\text { of capital } \\
\text { reduction }\end{array}$ & $\begin{array}{l}\text { Paid-in capital } \\
\text { at end of } \\
\text { previous } \\
\text { accounting } \\
\text { period }\end{array}$ \\
\hline 1 & Kawasaki Shipyards & November 1932 & $\Delta 72,000$ & 90,000 \\
\hline 2 & Ensuikō Sugar & March 1930 & A 17,438 & 34,875 \\
\hline 3 & Japan Steel Works & April 1932 & $\boldsymbol{\Delta} 15,000$ & 30,000 \\
\hline 4 & Asano Shipyards & June 1934 & $\boldsymbol{\Delta} 14,000$ & 26,500 \\
\hline 5 & Tainan Sugar & June 1926 & $\boldsymbol{\Delta} 12,703$ & 16,938 \\
\hline 6 & Tokyo Gas Electric Industry & May 1922 & A 12,246 & 17,460 \\
\hline 7 & Teikoku Linen & December 1928 & $\boldsymbol{\Delta} 10,625$ & 21,250 \\
\hline 8 & Toyo Muslin & May 1931 & $\boldsymbol{\Delta} 10,607$ & 11,785 \\
\hline 9 & Nihon Kokan & November 1921 & $\Delta 10,500$ & 21,000 \\
\hline 10 & Tokyo Muslin Spinning & November 1928 & $\Delta 10,381$ & 20,317 \\
\hline 11 & Kobe Steel Works & December 1928 & $\boldsymbol{\Delta} 10,000$ & 20,000 \\
\hline 12 & Shibaura Electric & November 1931 & $\Delta 10,000$ & 20,000 \\
\hline 13 & Japan Flour Mills & November 1928 & $\Delta$ 9,225 & 12,300 \\
\hline 14 & Teikoku Sugar & April 1923 & $\mathbf{A} 7,500$ & 18,750 \\
\hline 15 & Japan Flour Mills & November 1928 & $\boldsymbol{\Delta} 7,137$ & 11,075 \\
\hline 16 & Nippon Electric & December 1932 & $\Delta 6,563$ & 17,500 \\
\hline 17 & Nichiro Fishing & December 1921 & $\Delta 6,383$ & 4,750 \\
\hline 18 & Toyo Muslin & November 1926 & $\Delta 6,175$ & 16,250 \\
\hline 19 & Tokyo Gas Electric Industry & May 1933 & $\Delta 5,400$ & 5,377 \\
\hline 20 & Rasa Island Sulfate & March 1924 & $\Delta 5,250$ & 10,500 \\
\hline
\end{tabular}

Notes: (1) Cases shown are for those between 1918 and 1936 involving large capital reductions.

(2) There are cases where capital increased between the end of the previous accounting period and the time of capital reduction, so that in some cases the amount of capital reduction exceeds the amount of paid-in capital at the end of the previous accounting period.

Source: Extracted from the database created to draw up Table 2.

inordinate level of shareholder power can also bring about instability in corporate management. We can regard Japanese enterprises in the interwar period as a typical example of management instability brought about by strong shareholder power.

However, the occurrence of large-scale capital reductions suggests the possibility that it was shareholders that bore the costs incurred when dealing with company failures. In the sense that strong shareholder 
powers also entailed a corresponding cost burden in time of crisis, the system can be appreciated as having consistency. We can also contrast this system with the postwar Japanese enterprise system, where 'main banks' exercised strong authority over corporate management, and where the banks bore the cost burden when a client company fell into management difficulties, by reducing or forgoing interest payments, or by writing off debt.

\section{CONCLUSION}

This paper has attempted a reconsideration of corporate finance in large Japanese companies in the interwar period, with particular reference to its relationship with the enterprise system. In particular, it has focused on fund-raising through equities, which was the most significant method of fund-raising in this period. It has also considered the following three issues: (1) the role played by the system of paying for stocks by installments; (2) the influence of corporate mergers; and (3) the quantitative scale of capital reductions. From the results obtained, we can say that the following issues should be borne in mind when analyzing the corporate finance of large firms in the interwar period.

Firstly, with reference to the difference between new share issues and subsequent calls for the payment of partly-paid stocks, we saw that the latter kept at a substantial level, even during the period of continued business depression of the 1920s. This can be regarded as demonstrating one of the characteristics of fund-raising by demanding the paying-in of partly-paid stocks, namely that it reflected management discretion. If we bear in mind that corporate instability was regarded as a problem during the $1920 \mathrm{~s}^{33}$, we cannot deny the possibility that the fund-raising by subsequent calls for the paying-in of partly-paid stocks may have played a role in enabling the apothanasia of inefficient corporate management.

Secondly, whereas previous research has identified the 1930s as the peak period for corporate mergers before World War II, it is in fact the 1920s that showed the highest level of increases in paid-in capital due to mergers with other firms. If we recall that the 1920s are characterized as

33. Takahashi, op. cit 
a period of chronic depression, this fact suggests that there was a large number of firms that were rescued from collapse by being taken over by other firms. This is also connected with the following point, but we can conclude that in the 1920s there existed many firms whose management was so inefficient as to drive them to the point of collapse.

Thirdly, we must also note the fact that the decrease in paid-in capital resulting from capital reductions reached very high levels. One of the features of the interwar enterprise system was the strength of shareholders, but an over-emphasis on the distribution of profits to shareholders can raise the possibility of instability in a firm's operations. Consequently, the frequent occurrence of large-scale capital reductions can be considered an unavoidable cost of the system where shareholders were dominant. This point should not be overlooked if we are to achieve an accurate assessment of the interwar enterprise system, with its strong shareholder powers. Further, this is also an issue which should not be overlooked if we are to understand Japanese enterprises in recent years, when the influence of shareholders is on the increase. 